ЕКСПЕРИМЕНТАЛЬНА ТА КЛІНІЧНА ФАРМАКОЛОГІЯ

Recommended by Doctor of Medicine, professor N.M.Kononenko

UDC 616.992.282:615.371:615.015.33

\title{
COMPARISON OF THE ACTION OF ASSOCIATED ANTIGENS AND ASSOCIATED INACTIVATED CELLS OF C. ALBICANS AND C. TROPICALIS FUNGI
}

\author{
M.V.Rybalkin, N.I.Filimonova, L.S.Strelnikov \\ National University of Pharmacy \\ Key words: candidiasis; antigen; vaccine; immunity; therapy
}

\begin{abstract}
Many researchers believe that the use of drugs that can stimulate protective immune responses against candidal infections, i.e. immunobiological drugs stimulating the protective function, is promising in the fight against candidiasis. The aim of this work was to compare protective and therapeutic properties of the associated antigens and the associated inactivated cells of $C$. albicans and C. tropicalis fungi. The protective and therapeutic effects of the associated inactivated suspension of $C$. albicans and $C$. tropicalis fungi with the concentration of $10+10(\mathrm{~m} / \mathrm{ln} . \mathrm{c} / \mathrm{ml})$ and the associated antigens of C. albicans fungi with the protein concentration of $3 \mathrm{mg} / \mathrm{ml}$, and C. tropicalis with the protein concentration of $5 \mathrm{mg} / \mathrm{ml}$ in the ratio of 1:1 were compared. The research was carried out in healthy two month white mice weighing 18-22 g; there were six animals in the control and experimental groups each. As the result of the studies, it has been found that the use of the combined antigens of $C$. albicans and C. tropicalis provides $100 \%$ protective and therapeutic effects in mice. The inactivated suspension of C. albicans and $C$. tropicalis fungi provides $84 \%$ protective and therapeutic effect in mice for 3 months after intramuscular injection of $0.2 \mathrm{ml}$. In $16 \%$ of animals treated with the inactivated suspension of fungi the signs of a mild disease have been revealed. In future it is planned to substantiate experimentally the type and concentration of excipients such as preservatives, stabilizers and adjuvants in the composition of the solution of the associated antigens of C. albicans and C. tropicalis fungal cells.
\end{abstract}

In recent years, the number of patients with candidiasis has increased dramatically; it is associated with the irrational use of antibiotics, hormones, steroids, as well as environment deterioration, increased pathogenicity of Candida genus fungi and development of associated diseases [8]. Candidiasis is manifested in different forms, systemic and visceral candidiasis is the most dangerous [1]. They are characterized by a long course of disease, have a variety of clinical manifestations and frequent relapses. These forms of candidiasis are difficult to treat with modern medicines, including antifungal antibiotics $[1,8]$.

When treating candidiasis it is necessary to determine the type of a pathogen and its susceptibility to antifungal drugs. After determining the type of Candida fungus it is necessary to determine the antibiotic, to which this pathogen is sensitive, and adjust the dose and duration of therapy [8].

However, in the modern practice of doctors in this country identification of species of Candida fungus that is the causative agent of the disease is rare. Candidiasis caused by Candida genus fungi without specifying the type is diagnosed most often. It should be also noted that even if you want to identify the species of Candida fungus, it is not always possible to do due to the limi- ted reagents, equipment and experience of laboratory workers. In this situation, doctors prescribe the antifungal therapy according to the standard scheme using amphotericin B or fluconazole most often despite the fact that causative agents of this disease are not sensitive to these drugs. Besides, the long-term use of the same antifungal drugs has led to the loss of sensitivity to many species of Candida fungi or their individual epitopes $[1,8]$.

Many researchers believe that the use of drugs that can stimulate protective immune responses against candidal infections, i.e. immunobiological drugs stimulating the protective function, is promising in the fight against candidiasis [3-7], and they are an alternative of antifungal drugs. It should be noted that today there are several classifications of vaccines based on the method of preparation and the components [2]. However, there is no consensus among researchers - which of the vaccines is the most promising. It should be noted that a promising direction in the modern development of immunological agents that stimulate the body's defense mechanisms is creation of associated drugs against several pathogens simultaneously [9-11]. Therefore, it has been decided to compare the protective and therapeutic properties of the associated antigens and the associated inactivated cells of C. albicans and C. tropicalis fungi, 
which are major pathogens of candidiasis. Inactivated vaccines play an important role in preventing various infections. To produce them the required microorganisms causative agents are used. A microorganism is subjected to such treatment, which leads to the loss of the required capacity for reproduction (replication), but retains the antigenic and immunogenic properties. Antigens of cells are obtained by cell disruption followed by ultrafiltration; these drugs are called subunit [8].

The aim of this work was to compare protective and therapeutic properties of the associated antigens and the associated inactivated cells of C. albicans and C. tropicalis fungi.

\section{Materials and Methods}

To assess the ability to prevent candidiasis in mice with the combined inactivated suspension of $C$. albicans and $C$. tropicalis fungi with the concentration of $10+$ $10(\mathrm{mln} . \mathrm{c} / \mathrm{ml})$ and the associated antigens of C. albicans fungi with the protein concentration of $3 \mathrm{mg} / \mathrm{ml}$ and C. tropicalis with the protein concentration of $5 \mathrm{mg} / \mathrm{ml}$ in the ratio of 1:1 the research was carried out in healthy two month white mice weighing 18-22 g. There were six animals in the control and experimental groups each; they were kept in the same conditions on a standard diet. Before the research the animals acclimatized themselves under experimental room conditions. The combined inactivated cells of $C$. albicans and $C$. tropicalis fungi in the volume of $0.2 \mathrm{ml}$ were injected intramuscularly to the mice of one experimental group in the upper part of the rear right paw, and the combined antigens of $C$. albicans and C. tropicalis fungi in the volume of $0.2 \mathrm{ml}$ were injected intramuscularly to the mice of the second experimental group in the upper part of the rear right paw. In 14 days the combined inactivated cells of $C$. albicans and $C$. tropicalis fungi in the volume of $0.2 \mathrm{ml}$ were injected again in the upper part of the left rear paw of the first group, and the second group was injected in the upper part of the left rear paw with the combined antigens of $C$. albicans and C. tropicalis fungi in the volume of $0.2 \mathrm{ml}$. The animals of the control group were injected with the sterile $0.9 \%$ isotonic saline solution. The experimental animals of one group were infected intraperitoneally in a month after immunization, and in 3 months the second group was infected. For this purpose the suspension of Candida albicans fungi of CCM 335-867 strain in the amount of $20 \mathrm{mln}$. of cells and Candida tropicalis of ATTC 20336 strain in the amount of $60 \mathrm{mln}$. of cells in the volume of $1 \mathrm{ml}$ was used; the strains were introduced with an interval of 1 hour. After that in 14 days the animals were examined and the results were determined.

The therapeutic effect of the combined inactivated suspension of $C$. albicans and $C$. tropicalis fungi with the concentration of $10+10(\mathrm{mln} . \mathrm{c} . / \mathrm{ml})$ and the associated antigens $C$. albicans fungi with the protein concentration of $3 \mathrm{mg} / \mathrm{ml}$ and $C$. tropicalis fungi with the protein concentration of $5 \mathrm{mg} / \mathrm{ml}$ in the ratio of $1: 1$ was investigated in healthy two month white mice weighing 18-22 g; six animals in the control and experimental groups each; they were kept in the same conditions on a standard diet. Before the research the animals acclimatized themselves under experimental room conditions. The animals were infected intraperitoneally with the suspension of Candida albicans fungi of CCM 335-867 strain in the amount of $20 \mathrm{mln}$. of cells and Candida tropicalis of ATTC 20336 strain in the amount of $60 \mathrm{mln}$. of cells in the volume of $1 \mathrm{ml}$. In 5 days the combined inactivated cells of $C$. albicans and C. tropicalis fungi in the volume of $0.2 \mathrm{ml}$ were injected intramuscularly to the mice of one experimental group in the upper part of the rear right paw, and the combined antigens of $C$. albicans and C. tropicalis fungi in the volume of $0.2 \mathrm{ml}$ were injected intramuscularly to the mice of the second experimental group in the upper part of the rear right paw. In 14 days the combined inactivated cells of $C$. albicans and $C$. tropicalis fungi in the volume of $0.2 \mathrm{ml}$ were injected again in the upper part of the left rear paw of the first group, and the second group was injected in the upper part of the left rear paw with the combined antigens of $C$. albicans and C. tropicalis fungi in the volume of $0.2 \mathrm{ml}$. The animals of the control group were injected with the sterile isotonic saline solution.

\section{Results and Discussion}

As a result of the research conducted concerning prevention of candidal infections it has been found that the use of the combined antigens of $C$. albicans with the protein concentration of $3 \mathrm{mg} / \mathrm{ml}$ and $C$. tropicalis with the protein concentration of $5 \mathrm{mg} / \mathrm{ml}$ in the ratio of $1: 1$ provides a protective effect in $100 \%$ of mice for 3 months when introduced intramuscularly in the volume of $0.2 \mathrm{ml}$.

While the associated inactivated suspension of C. albicans and C. tropicalis fungi in the ratio of $10+10(\mathrm{mil} . \mathrm{c} / \mathrm{ml})$ provides a protective effect in $84 \%$ of mice for 3 months when introduced intramuscularly in the volume of $0.2 \mathrm{ml}$, $16 \%$ of the animals have shown the signs of a mild form of the disease $(+)$ - unkempt appearance, refusal to eat, the body weight loss, dysfunctions of the excretory organs (Tab. 1).

Table 1

Comparison of the protective action of the associated antigens and the associated inactivated cells of C. albicans and C. tropicalis fungi

\begin{tabular}{|c|c|c|c|c|c|c|}
\hline \multirow{2}{*}{ Medicine } & \multicolumn{7}{|c|}{ Test animals } \\
\cline { 2 - 7 } & 1 & 2 & 3 & 4 & 5 & 6 \\
\hline \multicolumn{7}{|c|}{ Results in 1 month } \\
\hline 1 & - & - & - & - & - & - \\
\hline 2 & - & - & + & - & - & - \\
\hline Control & ++ & +++ & ++ & +++ & ++ & +++ \\
\hline \multicolumn{7}{|c|}{ Results in 3 month } \\
\hline 1 & - & - & - & - & - & - \\
\hline 2 & - & - & - & + & - & - \\
\hline Control & ++ & +++ & +++ & +++ & ++ & +++ \\
\hline
\end{tabular}

Note: a) 1 - combined antigens of $C$. albicans and C. tropicalis fungi; 2 - combined inactivated cells of $C$. albicans and C. tropicalis fungi; b) " - " absence of the disease, "+" - a mild form of the disease, $"++"$ - a moderate form of the disease, " $+++"$ - an advanced form of the disease. 
Comparison of therapeutic effects of the associated antigens and the associated inactivated cells of C. albicans and C. Tropicalis fungi

\begin{tabular}{|c|c|c|c|c|c|c|}
\hline \multirow{4}{*}{ Animals } & \multicolumn{6}{|c|}{ Medicine } \\
\hline & \multicolumn{2}{|c|}{1} & \multicolumn{2}{|c|}{2} & \multicolumn{2}{|c|}{ Control } \\
\hline & \multicolumn{6}{|c|}{ Result } \\
\hline & after infection & $\begin{array}{c}\text { after the second } \\
\text { injection }\end{array}$ & after infection & $\begin{array}{c}\text { after the second } \\
\text { injection }\end{array}$ & after infection & $\begin{array}{c}\text { after the second } \\
\text { injection }\end{array}$ \\
\hline 1 & ++ & - & + & - & + & ++ \\
\hline 2 & + & - & ++ & - & ++ & +++ \\
\hline 3 & ++ & - & ++ & - & + & ++ \\
\hline 4 & + & - & ++ & + & ++ & +++ \\
\hline 5 & ++ & - & + & - & + & +++ \\
\hline 6 & ++ & - & ++ & - & ++ & +++ \\
\hline
\end{tabular}

Note: a) 1 - combined antigens of C. albicans and C. tropicalis fungi; 2 - combined inactivated cells of C. albicans and C. tropicalis fungi; b) " - " absence of the disease, " + " - a mild form of the disease, " ++ " - a moderate form of the disease, " +++ " - an advanced form of the disease.

According to the research of the therapeutic action it has been determined that the associated antigens of $C$. albicans fungi with the protein concentration of $3 \mathrm{mg} / \mathrm{ml}$ and $C$. tropicalis with the protein concentration of $5 \mathrm{mg} / \mathrm{ml}$ in the ratio of 1:1 provide a therapeutic effect in $100 \%$ of animals when introduced intramuscularly in the volume of $0.2 \mathrm{ml}$.

According to the research results it has been found that the associated inactivated suspension of C. albicans and C. tropicalis fungi provides the therapeutic effect in $84 \%$ of animals when introduced intramuscularly in the volume of $0.2 \mathrm{ml}$ and the concentration of $10+10(\mathrm{mln} . \mathrm{c} / \mathrm{ml})$. In $16 \%$ of the animals there were the signs of a mild form of the disease $(+)$ - unkempt appearance, refusal to eat, the body weight loss, dysfunctions of the excretory organs (Tab. 2).

The animals of the control groups showed the signs of a moderate form of the disease $(++)$ - adynamia, unkempt appearance, refusal to eat, the body weight loss, contractures of the neck muscles, the lateral location of the body, dysfunctions of the excretory organs, during autopsy when examining the mucous membranes of natural orifices there were signs of pathological processes, plating of fungi with faeces; and an advanced form of the disease $(+++)$ - adynamia, unkempt appearance, refusal to eat, the body weight loss, contractures of the neck muscles, paralysis of the limbs, convulsions, the lateral location of the body, dysfunctions of the excretory organs, during autopsy when examining the mucous membranes of natural orifices, internal organs of the animals the signs of such pathological processes as microabscesses in the renal cortical layer, lungs, spleen, liver, etc., as well as isolation of retrocultures of fungi from the animals' organs were revealed.

\section{CONCLUSIONS}

1. It has been determined that the associated antigens of C. albicans and C. tropicalis fungi compared to the associated inactivated cells of $C$. albicans and C. tropicalis fungi provide the best results both in preventing and in treating Candida infections within 3 months.

2. It has been found that the associated antigens of C. albicans and C. tropicalis provide $100 \%$ protective and therapeutic effects in the experimental animals.

3. It has been determined that 3 months is the term of the protective action for the associated antigens of C. albicans fungi with the protein concentration of $3 \mathrm{mg} / \mathrm{ml}$ and C. tropicalis with the protein concentration of $5 \mathrm{mg} / \mathrm{ml}$ in the ratio of $1: 1$.

4. In future it is planned to substantiate experimentally the type and concentration of excipients such as preservatives, stabilizers and adjuvants in the composition of the solution of the associated antigens of C. albicans and C. tropicalis fungal cells.

\section{REFERENCES}

1. Голубка O.B. // Annals of Mechnikov Institute. - 2011. - №2. - C. 51-59.

2. Жукова Н.В., Кривошеева И.М. // Кримський терапевт. журн. - 2013. - №2. - С. 99-104.

3. Carvalho A., Cunha C., Iannitti R.G. et al. // Front. Microbiol. - 2012. - Vol. 3. - P. 1-9.

4. Cassone A. // Lancet Infect. Dis. - 2008. - Vol. 8. - P. 114-124.

5. D’Argenio D.A., Wilson C.B. // Immunity. - 2010. - Vol. 33, №4. -P. 437-440.

6. Grover A., Bhandari B.S., Rai N., Lakhera P.C. // Biotechnol. International. - 2010. - Vol. 3, №1. - P. 4-17.

7. Han Y., Rhew K.Y. // Arch. Pharm. Res. - 2012. - №35. - P. 2021-2027.

8. LeibundGut-Landman S., Wutrich M., Hohl T. // Curr. Opin. Immunol. - 2012. - Vol. 24. - P. 1-10. 
9. Nabel G.J. // N. Eng. J. Med. - 2013. - Vol. 6, №368. -P. 551-60.

10. Petrov P.V., Khaitov R.M. Immunogens and New Generation Vaccine. - M.: GEOSTAR-Medicine, 2011. - 608 p.

11. Skibinski A.G.D., Baudner C.B., Manmohan S. et al. // Glob. Infect. Dis. - 2011. - Vol. 3, №1. -P. 63-72.

ПОРІВНЯННЯ ДІЇ АСОЦІЙОВАНИХ АНТИГЕНІВ ТА АСОЦІЙОВАНИХ ІНАКТИВОВАНИХ КЛITИН ГРИБІВ С. ALBICANS TA C. TROPICALIS

М.В.Рибалкін, Н.І.Філімонова, Л.С.Стрельников

Ключові слова: кандидамікоз; антиген; вакцина; імунітет; терапія

Багато дослідників вважає, що використання препаратів, які здатні стимулювати захисні імунні реакції проти кандидозної інфрекції, тобто імунобіологічні препарати, які стимулюють протективні фрункції, є перспективним напрямком у боротьбі з кандидозом. Метою даної роботи було порівняння проективних і терапевтичних властивостей асоційованих антигенів та асоційованих інактивованих клітин грибів C. albicans ma C. tropicalis. Порівнювались протективні та терапевтичні дії поєднаної інактивованої суспензії грибів C. albicans та C. tropicalis з концентрацією $10+10$ (млн кл./мл) та поєднаних антигенів грибів C. albicans 3 концентрацією білка 3 мә/мл та C. tropicalis з концентрацією білка 5 мг/мл у співвідношенні 1:1. Дослідження проводили на здорових білих мишах двомісячного віку масою 18-22 г по 6 особин у контрольних і дослідних групах. У результаті проведених досліджень встановлено, що застосування поєднаних антигенів C. albicans ma C. tropicalis забезпечує протективний та терапевтичний ефект у 100\% мишей, а інактивована суспензія грибів C. albicans та C. tropicalis забезпечує протективний та терапевтичний ефект у 84\% мишей протягом 3 місяців при внутрішньом'язовому введенні по 0,2 мл. У 16\% тварин, яким вводили інактивовану суспензію грибів, виявлялись ознаки слабкої фоорми захворювання. У подальшому планується у складі одержаного розчину асоційованих антигенів клітин грибів C. albicans ma C. tropicalis експериментально обгрунтувати тип і концентрацію допоміжних речовин, таких як консерванти, стабілізатори та ад'юванти.

\section{СРАВНЕНИЕ ДЕЙСТВИЯ АССОЦИИРОВАННЫХ АНТИГЕНОВ И АССОЦИИРОВАННЫХ ИНАКТИВИРОВАННЫХ КЛЕТОК ГРИБОВ С. ALBICANS И С. TROPICALIS \\ Н.В.Рыбалкин, Н.И.Филимонова, Л.С.Стрельников}

Ключевые слова: кандидамикоз; антиген; вакцина; иммунитет; терапия

Многие исследователи считают, что использование препаратов, которые способны стимулировать защитные иммунные реакции против кандидозной инфекции, m. е. иммунобиологические препараты, которые стимулируют протективные фрункции, является перспективным направлением в борьбе с кандидозом. Целью данной работы было сравнение проективных и терапевтических свойств ассоциированных антигенов и ассоциированных инактивированных клеток грибов C. albicans и C. tropicalis. Сравнивались протективное и терапевтическое действие ассоциированной инактивированной суспензии грибов C. albicans u C. tropicalis $c$ концентрацией 10 + 10 (млн кл./мл) и ассоциированных антигенов грибов C. albicans c концентрацией белка 3 мг/мл и C. tropicalis с концентрацией белка 5 мг/мл в соотношении 1:1. Исследования проводили на здоровых белых мышах двухмесячного возраста массой 18-22 г по 6 животных в контрольных и опытных группах. В результате проведенных исследований установлено, что применение объединенных антигенов C. albicans и C. tropicalis обеспечивает протективный и терапевтический эфрфект в 100\% мышей, а инактивированная суспензия грибов C. albicans и C. tropicalis обеспечивает протективный и терапевтический эфрфект у 84\% мышей в течение 3 месяцев при внутримышечном введении по 0,2 мл. В 16\% случаев у животных, которым вводили инактивированную суспензию грибов, проявлялись признаки слабой фрормы заболевания. В дальнейшем планируется в составе полученного раствора ассоциированных антигенов клеток грибов C. albicans и C. tropicalis экспериментально обосновать тип и концентрацию вспомогательных веществ, таких как консерванты, стабилизаторы и адъюванты. 